\title{
Pengembangan Model Pembelajaran Diskusi dan Personal Investigation dalam Meningkatkan Pemahaman Mahasiswa pada Mata Kuliah Evaluasi Pembelajaran di Universitas Batanghari
}

\author{
Pratiwi Indah Sari $^{1^{*}}$, Kartika Dewi ${ }^{2}$, Fitri Ayuningsih ${ }^{3}$ \\ ${ }^{1,2,3}$ Program Studi Pendidikan Ekonomi, FKIP UNBARI \\ "Correspondence email: pradasari67@gmail.com
}

\begin{abstract}
Errors in this learning process also occur in tertiary education. Some lecturers sometimes only focus on providing material with the aim of pursuing material achievement, so they don't think about how students understand it. This should not happen again in education, especially higher education, where students have been able to develop their own knowledge given. At the tertiary level, students must be able to develop what is in them. Students should be able to obtain information, solve problems that occur in learning. Based on the results of data analysis that have been obtained previously, there is a difference between the use of the lecture method with the discussion learning model and personal investigation on students of the Economic Education Study Program and the English Education Study Program, the Teacher Training and Education Faculty, Batanghari University in the Learning Evaluation course. This means that the application of new teaching methods can certainly have an impact and change even without eliminating the meaning of the learning itself. Thus, the application of the learning model is not only to attract students' interest and attention to the provision of lecture material, but to familiarize themselves so that they want to develop themselves in receiving information so that in the end it will improve their learning outcomes. This is because students are the final level in a learning process which is expected not only to have good character and personality, but also to have insight and knowledge globally as well.
\end{abstract}

Keywords : Discussion and Personal Investigation Method

\section{PENDAHULUAN}

Fakultas Keguruan dan Ilmu Pendidikan, Universitas Batanghari sebagai salah satu contoh dimana masih banyak dosen menerapkan pembelajaran bersifat ceramah kepada mahasiswa. Padahal FKIP sebagai fakultas yang melahirkan calon pendidik yang profesional hendaknya lebih dapat mengembangkan model pembelajaran yang dapat meningkatkan pemahaman dan kreativitas mahasiswa, bukan hanya memberikan ceramah dan diskusi yang hanya berjalan satu arah dan cenderung vakum dalam prakteknya. Sebagai pendidik yang mendidik peserta didik tingkat universitas seharusnya lebih mampu untuk menemukan solusi dalam menghadapi kendala dalam proses pembelajaran.

Hal ini sejalan dengan visi dan misi dari Fakultas Keguruan dan Ilmu Pendidikan itu sendiri yang selalu senantiasa melakukan penyesuaian dengan kurikulum nasional dan memperhatikan relevansinya dengan dunia kerja. Maka, dalam perkuliahan setidaknya ditampilkan dan disajikan bagaimana cara dalam mengembangkan wawasan dan pengembangan kemampuan mahasiswa dalam mengikuti materi yang diberikan. Namun, hingga saat ini masih banyak terdapat kendala yang belum dapat dimaksimalkan dan mampu dilaksanakan pada setiap mata kuliah yang ditawarkan kepada mahasiswa.

Salah satu mata kuliah yang terkadang hanya diberikan berupa teori saja dalam prosesnya adalah evaluasi pembejaran. Evaluasi pembelajaran merupakan mata kuliah prasyarat mahasiswa untuk bisa mengikuti kegiatan pelaksanaan pengalaman lapangan (PPL).
Seharusnya mata kuliah ini mengajarkan mahasiswa untuk membuat soal pembelajaran yang layak, mengajarkan mengevaluasi, menilai peserta didik. Tapi dalam prakteknya terkadang dosen hanya materi saja yang diberikan tanpa mengajarkan mahasiswa bagaimana mengelola soal yang baik.

Mata kuliah evaluasi pembelajaran dan perencanaan pembelajaran merupakan mata kuliah yang penting untuk mengembangkan kemampuan mengajar guru. Penguasaan mata kuliah evaluasi pembelajaran dan perencanaan pembelajaran dapat menumbuhkan kemampuan guru dalam pengelolaan pembelajaran peserta didik. Kemampuan tersebut termasuk dalam kompetensi pedagogik yang wajib dimiliki guru. Pasal 10 Undang-Undang Tahun 2005, tentang Guru dan Dosen menjelaskan kompetensi guru sebagaimana dimaksud dalam Pasal 8 yang meliputi kompetensi pedagogi, kompetensi kepribadian, kompetensi sosial, dan kompetensi profesional yang diperoleh melalui pendidikan profesi.

Berdasarkan observasi yang dilakukan pada lima Program Studi yang dilakukan di Fakultas Keguruan dan Ilmu Pendidikan, Universitas Batanghari, yakni Pendidikan Bahasa Indonesia dan Sastra Indonesia, Pendidikan Bahasa Inggris, Pendidikan Sejarah, Pendidikan Ekonomi, dan Pendidikan Matematika. Hanya dua Program Studi yang menerapkan pembelajaran yang bersifat kooperatif yakni Pendidikan Sejarah dan Pendidikan Ekonomi. Sedangkan, tiga Program Studi lain masih menerapkan model cermah dan diskusi klasik. Inilah menjadi salah satu penyebab 
Pratiwi Indah Sari et al, Pengembangan Model Pembelajaran Diskusi dan Personal Investigation dalam Meningkatkan Pemahaman Mahasiswa pada Mata Kuliah Evaluasi Pembelajaran di Universitas Batanghari

masih banyak mahasiswa tidak paham mengenai evaluasi pembelajaran.

Dalam sistem pembelajaran, evaluasi merupakan suatu komponen penting dan tahap yang harus dilaksanakan oleh seorang guru untuk dapat mengetahui efektifitas dan efisiensi proses serta kegiatan pembelajaran yang dilakukan. Hal ini dikarenakan, hasil yang diperoleh dari pelaksanaan evaluasi tersebut dapat dijadikan balikan (feed-back) bagi guru dalam memperbaiki dan menyempurnakan program dan kegiatan pembelajaran. Dimana, hal tersebut dapat dilakukan dengan memberikan tugas harian, ujian tengah semester baik lisan maupun tulisan, dan ujian akhir semester.

Adapun tujuan akhir dari proses pembelajaran ini sendiri tidak lain bertujuan agar tujuan pembelajaran tercapai dan diterima dengan baik oleh peserta didik, sehingga dapat memenuhi kompetensi guru yang profesional. Artinya, mahasiswa tidak hanya mengetahui tujuan akhir mereka menjadi tenaga pendidik dari perkuliahan, namun juga mendapatkan wawasan dan mengalami peningkatan dalam pengalaman mereka untuk menjadikan karakteristik dan kepribadian mereka benar-benar memahami bagaimana menjadi tenaga pendidik yang profesional.

Model tersebut merupakan pola umum perilaku pembelajaran untuk mencapai kompetensi/tujuan pembelajaran yang diharapkan. Dalam suatu model pembelajaran ditentukan bukan hanya apa yang harus dilakukan guru, akan tetapi menyangkut tahapantahapan, prinsip-prinsip reaksi guru dan siswa serta sistem penunjang yang disyaratkan. Oleh karena itu, usaha guru dalam membelajarkan peserta didik merupakan bagian yang sangat penting dalam mencapai keberhasilan tujuan pembelajaran yang sudah direncanakan.

Kegitan pembelajaran yang dilakukan pendidikan banyak menggunakan model pembelajaran. Model ini merupakan representasi dari suatu objek yang akan diajarkan kepada peserta didik. Model pembelajaran biasa berupa, benda, atau ide-ide yang disederhanakan dari kondisi dan fenomena yang terjadi. Menurut Trianto (2014), model pembelajaran merupakan suatu objek atau konsep yang digunakan dalam mempresentasekan suatu hal yang nyata dan konvensional kedalam bentuk yang lebih komprehensif. Hal ini berarti model pembelajaran merupakan gambaran mini dari yang akan dipelajari sehingga peserta didik dapat lebih memahani tentang materi. Sedangkan teori lainnya

Menurut Locke (2014) model pembelajaran memiliki peran penting dalam menerapkan metode pembelajaran baik secara modern mapn konvensional. Ini diperkuat dengan teori Arends dalam Fathurrohman (2015) yang memberikan pengertian bahwa model pembelajaran adalah suatu rencana mapun pola yang membantu peserta didik mempelajari secara spesifik dari berbagai ilmu pengetahuan, sikap dan keterampilan.
Selain itu Suprijono (2015) memberikan pengertian bahwa model pembelajaran merupakan pedoman yang digunakan dalam merencanakan pembelajaran baik dikelas mapun tutorial.

Menurut Joyce dan Will dalam Huda (2014) model pengajaran merupakan rencana maupun pola yang disusun dalam kurikulum, desain instruksional dan panduan proses pengajaran didalam kelas. Berdasarkan teori diatas dapat disimplkan bahwa model pembelajaran merupakan disain yang dapat membantu peserta didik dalam memahami pembelajaran sehingga tercapai tjuan pembelajaran.

Diskusi termasuk ke dalam salah satu model pembelajaran yang sering digunakan. Diskusi ini mendorong peserta didik untuk berdialog dan bertukar pikiran serta berpartisipasi aktif dalam suatu kegiatan. Menurut Trianto (2014:56) diskusi merupakan suatu percakapan ilmiah yang dilakukan oleh beberapa orang yang tergabung dalam suatu kelompok yang bertujuan untuk saling bertukar pendapat tentang suatu masalah serta bersama-sama mencari pemecahan masalah. Sementara, Anurrahman (2014), model personal merupakan model yang menekankan pada rasa percaya diri dalam kegiatan pembelajaran. Hal ini dipertegas oleh teori Sagala (2015) bahwa model ini berorientasi pada perkembangan individu dalam membentuk dan menata keunikan yang ada dalam diri individu.

Investigation (investigasi) menurut Aisyah (2016) diartikan sebagai penyelidikan dengan cara mencatat ataupun merekam fakta-fakta, melakukan peninjauan dengan tujuan memperoleh jawaban atas pertanyaan tentang suatu peristiwa atau sifat. Sedangkan, menurut Krismanto (2014) menyatakan bahwa investigasi adalah kegiatan mengobservasi secara rinci dan sistematis. Dengan demikian, personal investigation adalah suatu model pembelajaran dimana mahasiswa secara individual memecahkan masalah yang ditemukan melalui penyelidikan, mencari fakta, merekam bukti yang diperoleh kemudian melakukan peninjauan sesuai dengan literature yang menjadi dasar.

Model pembelajaran diskusi dan investigasi (discussion and personal investigation) merupakan model pembelajaran yang melakukan penggabungan antara metode diskusi dan investigasi individu, model ini menitikberatkan pada kerjasama yang dilakukan kelompok dan melatih individu dari setiap peserta didik untuk lebih kritis dalam menafsirkan suatu materi. Model pembelajaran diskusi dan investigasi (discussion and personal investigation) adalah model pembelajaran dimana mahasiswa dalam kelompok saling bertukar pendapat tentang permasalahan yang ada kemudian bersama-sama untuk mencari pemecahan masalah dan setelah itu masing masing mahasiswa melakukan penyelidikan kemudian mencatat fakta yang ditemukan, meninjau kembali kesesuaian dengan literatur dan secara pribadi menginterprestasi berdasarkan sumber sumber yang diperoleh. 
Pratiwi Indah Sari et al, Pengembangan Model Pembelajaran Diskusi dan Personal Investigation dalam Meningkatkan Pemahaman Mahasiswa pada Mata Kuliah Evaluasi Pembelajaran di Universitas Batanghari

Dalam Peraturan Menteri Pendidikan Nasional Nomor 41 Tahun 2007 mengenai Standar Proses untuk Satuan Pendidikan Dasar dan Menengah, diuraikan bahwa: "pembelajaran adalah proses interaksi peserta didik dengan guru dan sumber belajar pada suatu lingkungan belajar. Proses pembelajaran perlu direncanakan, dilaksanakan, dinilai, dan diawasi. Pelaksanaan pembelajaran merupakan implementasi dari RPP. Pelaksanaan pembelajaran meliputi kegiatan pendahuluan, kegiatan inti dan kegiatan penutup". Maka, pada kegiatan belajar mengajar, metode diperlukan oleh guru agar penggunaannya bervariasi sesuai yang ingin dicapai setelah pengajaran berakhir.

\section{METODE}

Berdasarkan permasalahan yang telah dijelaskan sebelumnya maka dapat disimpulkan bahwa, penelitian yang dilakukan oleh penulis merupakan penelitian eksperimen seperti yang dikemukakan oleh Sugiyono (2014), menjelaskan metode penelitian eksperimen adalah metode penelitian yang digunakan untuk mencari pengaruh perlakuan tertentu terhadap yang lain dalam kondisi yang terkendalikan. Penelitian eksperimen ini melibatkan dua kelas, yaitu kelas eksperimen dan kelas kontrol dengan perlakuan yang berbeda. Kelas eksperimen diberi perlakuan dengan model pembelajaran Diskusi dan Personal Investigation sementara pada kelas kontrol diberikan model pembelajaran ceramah. Setelah diberikan perlakuan, mahasiswa diberikan tes akhir untuk mengetahui pengaruh perlakuan tersebut terhadap hasil belajar mereka, atau pada perguruan tinggi disebut dengan Indeks Prestasi.

Adapun beberapa langkah yang akan dilakukan sebelum melakukan penelitian dalam bentuk eksperimen pada mahasiswa Fakultas Keguruan dan Ilmu Pendidikan, antara lain sebagai berikut:

1. Memilih unit percobaan.

2. Menentukan kelas yang menjadi eksperimen dan kontrol.

3. Memberikan Pre-Test untuk kels eksperimen dan kelas kontrol dan menghitung rata-rata hasil pretes.

4. Uji perbedaan Pre-Test antara kelas eksperimen dan kontrol.

5. Melaksanakan ekperimen dengan cara memakai model Diskusi dan Personal Investigation pada kelas eksperimen dan model ceramah pada kelas kontrol.

6. Memberikan Post-Test pada kedua kelas untuk mengukur perubahan yang terjadi.

7. Menganalisis pelaksanaan eksperimen yang dicapai dengan hasil yang diperoleh.

\section{HASIL DAN PEMBAHASAN}

Untuk menganalisis hasil pengolahan data dalam penelitian yang dilaksanakan, maka dapat dilaksanakan dengan teknik analisis data dengan analisis perbandingan yang pertama kali digunakan melalui pre-test awal dan akhir baik pada kelas kontrol maupun kelas eksperimen, sebagai berikut:

Tabel 1. Nilai Pre-Test Kelas Kontrol

\begin{tabular}{|c|c|c|c|c|c|c|}
\hline \multirow{3}{*}{ No. } & \multicolumn{6}{|c|}{ Kelas Kontrol } \\
\hline & \multirow{2}{*}{ Interval } & \multicolumn{2}{|c|}{ Pre-Test Awal } & \multirow{2}{*}{ Interval } & \multicolumn{2}{|c|}{ Pre-Test Akhir } \\
\hline & & $\mathbf{F i}$ & $\%$ & & $\mathbf{F i}$ & $\%$ \\
\hline 1. & $22,5-33,5$ & 5 & 20 & $32,5-42,5$ & 6 & 24 \\
\hline 2. & $33,6-44,6$ & 11 & 44 & $42,6-52,6$ & 4 & 16 \\
\hline 3. & $44,7-55,7$ & 2 & 8 & $52,7-62,7$ & 2 & 8 \\
\hline 4. & $55,8-66,8$ & - & - & $62,8-72,8$ & 10 & 40 \\
\hline \multirow[t]{2}{*}{5.} & $66,9-77,9$ & 7 & 28 & $72,9-82,9$ & 3 & 12 \\
\hline & Jumlah & 25 & 100 & Jumlah & 25 & 100 \\
\hline
\end{tabular}

Tabel 2. Nilai Pre-Test Kelas Eksperimen

\begin{tabular}{|c|c|c|c|c|c|c|}
\hline \multirow{3}{*}{ No. } & \multicolumn{6}{|c|}{ Kelas Eksperimen } \\
\hline & \multirow{2}{*}{ Interval } & \multicolumn{2}{|c|}{ Pre-Test Awal } & \multirow{2}{*}{ Interval } & \multicolumn{2}{|c|}{ Pre-Test Akhir } \\
\hline & & $\mathbf{F i}$ & $\%$ & & $\mathbf{F i}$ & $\%$ \\
\hline 1. & $25-33$ & 5 & 17,24 & $45-50$ & 9 & 31,03 \\
\hline 2. & $34-42$ & 8 & 27,59 & $51-56$ & 3 & 10,34 \\
\hline 3. & $43-51$ & 8 & 27,59 & $57-62$ & 1 & 3,45 \\
\hline 4. & $52-60$ & - & - & $63-68$ & - & - \\
\hline 5. & $61-69$ & - & - & $69-74$ & 14 & 48,28 \\
\hline 6. & $70-78$ & 8 & 27,59 & $75-80$ & 2 & 6,90 \\
\hline & Jumlah & 29 & 100 & Jumlah & 29 & 100 \\
\hline
\end{tabular}

Setelah diketahui nilai dari masing-masing kelas dalam mengetahui nilai pre-test awal dan akhir maka selanjutnya akan dicari nilai post-test pada masing- masing kelas, yaitu kelas kontrol dan kelas eksperimen, sebagai berikut: 
Pratiwi Indah Sari et al, Pengembangan Model Pembelajaran Diskusi dan Personal Investigation dalam Meningkatkan Pemahaman Mahasiswa pada Mata Kuliah Evaluasi Pembelajaran di Universitas Batanghari

Tabel 3. Nilai Post-Test Masing-masing Kelas

\begin{tabular}{|c|c|c|c|c|c|c|}
\hline \multirow{3}{*}{ No. } & \multicolumn{3}{|c|}{ Kelas Kontrol } & \multicolumn{3}{|c|}{ Kelas Eksperimen } \\
\hline & \multirow{2}{*}{ Interval } & \multicolumn{2}{|c|}{ Ceramah } & \multirow{2}{*}{ Interval } & \multicolumn{2}{|c|}{ Diskusi dan Personal Investigation } \\
\hline & & $\mathbf{F i}$ & $\%$ & & $\mathbf{F i}$ & $\%$ \\
\hline 1. & $47,5-55,5$ & 2 & 8 & $37,5-44,5$ & 6 & 20,69 \\
\hline 2. & $55,6-63,6$ & 1 & 4 & $44,6-51,6$ & 6 & 20,69 \\
\hline 3. & $63,7-71,7$ & 11 & 44 & $51,7-58,7$ & 2 & 6,90 \\
\hline 4. & $71,8-79,8$ & 7 & 28 & $58,8-65,8$ & 7 & 24,14 \\
\hline 5. & $79,9-87,9$ & 4 & 16 & $65,9-72,9$ & 5 & 17,24 \\
\hline 6. & & & & $73-80$ & 3 & 10,34 \\
\hline & Jumlah & 25 & 100 & & 29 & 100 \\
\hline
\end{tabular}

Adapun uji hipotesis dalam penelitian ini menggunakan uji rata-rata standard deviasi. Uji kesamaan dua rata-rata yang bertujuan untuk

menentukan hasil belajar ekonomi materi perdagangan internasional maka diperoleh data sebagai berikut:

Tabel 4. Frekuensi Mean Pada Kelas Kontrol

\begin{tabular}{ccccccc}
\hline No. & Interval & $\mathbf{F}$ & $\mathbf{X}$ & $\mathbf{F X}$ & $\mathbf{X}^{\mathbf{2}}$ & $\mathbf{F}\left(\mathbf{X}^{\mathbf{2}}\right)$ \\
\hline 1. & $47,5-55,5$ & 2 & 2 & 4 & 4 & 8 \\
2. & $55,6-63,6$ & 1 & 1 & 1 & 1 & 1 \\
3. & $63,7-71,7$ & 71 & 0 & 0 & 0 & 0 \\
4. & $71,8-79,8$ & 4 & -1 & -7 & 1 & 7 \\
5. & $79,9-87,9$ & -2 & -8 & 4 & 16 \\
& Jumlah & $\mathbf{2 5}$ & & $\mathbf{- 1 0}$ & $\mathbf{1 0}$ & $\mathbf{3 2}$ \\
\hline
\end{tabular}

Tabel 5. Frekuensi Mean Pada Kelas Eksperimen

\begin{tabular}{ccccccc}
\hline No. & Interval & $\mathbf{F}$ & $\mathbf{X}$ & $\mathbf{F X}$ & $\mathbf{X}^{\mathbf{2}}$ & $\mathbf{F}\left(\mathbf{X}^{\mathbf{2}}\right)$ \\
\hline 1. & $37,5-44,5$ & 6 & 3 & 18 & 9 & 54 \\
2. & $44,6-51,6$ & 6 & 2 & 12 & 4 & 24 \\
3. & $51,7-58,7$ & 2 & 1 & 2 & 1 & 7 \\
4. & $58,8-65,8$ & 7 & -1 & -7 & 1 & 20 \\
5. & $65,9-72,9$ & 5 & -2 & -10 & 4 & 27 \\
6. & $73-80$ & 3 & -3 & -9 & 9 & $\mathbf{2 8}$ \\
& Jumlah & $\mathbf{2 9}$ & & $\mathbf{6}$ & $\mathbf{2 8}$ \\
\hline
\end{tabular}

Setelah data tersebut diolah untuk mengetahui besarnya standar deviasi, adapun perhitungan standar deviasi dapat dilihat, sebagai berikut:

Standar Deviasi untuk kelas Kontrol:

$$
\begin{aligned}
& \mathrm{SD}=i \sqrt{\frac{\sum F(X)}{N}-\frac{\left(\sum F X 2\right)}{N}} \\
& \mathrm{SD}=5 \sqrt{\frac{(-10-(32))}{25} 25} \\
& \mathrm{SD}=5 \sqrt{-0,4+1,28} \\
& \mathrm{SD}=0,88
\end{aligned}
$$

Standar Deviasi untuk Kelas Eksperimen:

$\mathrm{SD}=\mathrm{i}\left(\underline{\left.\mathrm{F}(\mathrm{X})-\left(\sum \mathrm{FX} 2\right)\right)}\right.$

$$
\begin{aligned}
& \mathrm{SD}=7 \sqrt{\frac{(6-(134)}{29} 29} \\
& \mathrm{SD}=5 \sqrt{0,21+4,55} \\
& \mathrm{SD}=4,76
\end{aligned}
$$

Setelah diketahui nilai standar deviasi maka dapat dihitung dua rata-rata, sebagai berikut:

$\mathrm{t}=\mathrm{X} 1-\mathrm{X} 2$

$$
\begin{aligned}
& \overline{\mathrm{SX} 1-\mathrm{SX} 2} \\
= & \frac{25-29}{0,88-4,74} \\
= & -4 /-3,86 \\
= & 1,04
\end{aligned}
$$

Dari data tersebut, maka diketahui nilai uji rata-rata yang diperoleh sebesar 1,04.

\section{Pembahasan}

Hasil Belajar Mahasiswa Kelas Kontrol Yang Menggunakan Model Pembelajaran Ceramah Pada Mata Kuliah Evaluasi Pembelajaran

Berdasarkan uraian tabel analisa sebelumnya, dapat dijelaskan bahwa mahasiswa pada kelas kontrol masih mengalami sedikit perubahan dalam memperoleh nilai. Hal ini dikarenakan, pada saat pre-test mahasiswa Program Studi Pendidikan Ekonomi belum diberikan materi, karena pada saat pre-test merupakan kemampuan mahasiswa yang diperoleh dari informasi. Pada saat post-test yang merupakan tes yang diberikan terakhir dan mahasiswa sudah dibekali dengan materi dan penggunaan model ceramah terdapat peningkatan yang cukup signifikan pada hasil belajar mereka. 
Hal ini sependapat dengan hasil penelitian Subagiyo (2010), yang menjelaskan bahwa prestasi belajar pada metode ceramah lebih baik dari pada metode demonstrasi. Pada tempat penelitian yaitu di STIKES Muhammadiyah lamongan dosen dalam memberikan metode ceramah dilengkapi dengan sarana dan prasarana yang memadai antara lain Wearless, LCD, penataan kelas yang memungkinkan dosen bisa mengamati mahasiswa satu per satu sehingga mahasiswa lebih antusias mendengarkan ceramah dari dosen.

\section{Hasil Belajar Mahasiswa Kelas Eksperimen Yang Menggunakan Model Pembelajaran Diskusi dan Personal Investigation Pada Mata Kuliah Evaluasi Pembelajaran}

Berdasarkan uraian tabel analisa data sebelumnya, pada saat melaksanakan pre-test mahasiswa Program Studi Pendidikan Bahasa Inggris masih kesulitan dalam memahami apa yang diinginkan dari pelaksanaan model pembelajaran yang dimaksud. Akan tetapi, pada saat melaksanakan pre-test yang telah diberikan penjelasan terkait penggunaan model dan pemberian materi terdapat peningkatan meskipun belum secara keseluruhan. Dan, pada saat pelaksanaan post-test mahasiswa Program Pendidikan Bahasa Inggris sudah mulai terbiasa dengan penerapan model pembelajaran dan mendapatkan hasil belajar yang baik.

Hal ini sependapat dengan hasil penelitian Sarni (2013), yang menjelaskan bahwa secara keseluruhan hasil dari model implementasi model pembelajaran diskusi dan personal investigation lebih baik dari pada model pembelajaran yang sudah guru terapkan selama ini yaitu menggunakan meode ceramah dan tanya jawab. Oleh karena itu, model pembelajaran diskusi dan personal investigation yang sudah diimplementasikan dalam pembelajaran sejarah sudah layak dan sesuai diterapkan dalam pembelajaran sejarah di kelas.

\section{Perbandingan Hasil Belajar Pada Kelas Kontrol dan Kelas Eksperimen di Fakultas Keguruan dan Ilmu Pendidikan, Universitas Batanghari}

Berdasarkan hasil analisis data yang telah diperoleh sebelumnya, maka terdapat perbedaan antara penggunaan metode ceramah dengan model pembelajaran diskusi dan personal investigation pada mahasiswa Program Studi Pendidikan Ekonomi dan Program Studi Pendidikan Bahasa Inggris, Fakultas Keguruan dan Ilmu Pendidikan, Universitas Batanghari pada mata kuliah Evaluasi Pembelajaran. Artinya, dengan penerapan cara mengajar yang baru tentu dapat memberikan dampak dan perubahan meski tanpa menghilangkan makna dari pembelajaran itu sendiri.

Affandi, dkk (2013), menjelaskan bahwa model dan metode pembelajaran dapat didefinisikan bahwa model pembelajaran adalah prosedur atau pola sistematis yang digunakan sebagai pedoman untuk mencapai tujuan pembelajaran didalamnya terdapat strategi, teknik, metode, bahan, media dan alat penilaian pembelajaran. Sedangkan, metode pembelajaran adalah cara atau tahapan yang digunakan dalam interaksi antara peserta didik dan pendidik untuk mencapai tujuan pembelajaran yang telah ditetapkan sesuai dengan materi dan mekanisme metode pembelajaran.

Dengan demikian, penerapan model pembelajaran tidak semata untuk menarik minat dan perhatian mahasiswa terhadap pemberian materi perkuliahan saja, melainkan membiasakan diri mereka agar mau mengembangkan dirinya sendiri dalam menerima informasi sehingga pada akhirnya akan meningkatkan hasil belajar mereka. Hal ini dikarenakan, mahasiswa adalah tingkatan akhir dalam sebuah proses pembelajaran yang diharapkan tidak hanya karakter dan kepribadian yang memiliki akhlak yang baik, tetapi memiliki wawasan dan pengetahuan secara global pula.

\section{SIMPULAN}

1. Hasil belajar mahasiswa kelas kontrol, yakni pada Program Studi Pendidikan Ekonomi dengan menggunakan metode ceramah memperoleh persentase sebesar 16\%. Hal ini dikarenakan, mahasiswa kurang termotivasi dan cenderung tidak aktif dalam kegiatan pembelajaran.

2. Hasil belajar mahasiswa kelas eksperimen, yakni pada Program Studi Pendidikan Bahasa Inggris dengan menggunakan metode diskusi dan personal investigation memperoleh persentase sebesar $10,34 \%$. Hal ini dikarenakan, sebagian mahasiswa masih harus membiasakan diri untuk bekerja sama aktif dalam pembelajaran.

3. Dari kedua model pembelajaran tersebut, terdapat perbedaan hasil belajar mahasiswa dengan menggunakan model pembelajaran ceramah (16\%), dan model pembelajaran diskusi dan personal investigation $(10,34 \%)$.

\section{DAFTAR PUSTAKA}

Aunurrahman. 2014. Belajar dan Pembelajaran. Bandung: Alfabeta.

Drever, Jamies. 1986. Kamus Psikologi. Jakarta: Bina Aksara.

Fathurrohman, Muhammad. 2015. Model-model Pembelajaran Inovatif. Yogyakarta: Ar-ruzz Media.

Huda, M. 2014. Model-model Pengajaran dan Pembelajaran. Yogyakarta: Pustaka Pelajar.

Krismanto. 2014. Implementasi Kurikulum 2013 Konsep \&. Penerapan. Surabaya: Kata Pena.

Locke, Mirrin. 2014. Strategic Planning and Management in the MICE sector-A Case study of the Auckland Region. The University of Waikato.

Sagala, Syaiful. 2015. Supervisi Pembelajaran. Bandung: Alfabeta.

Sarni. 2013. Pengembangan Model Pembelajaran Diskusi dan Personal Investigation dalam 
Pratiwi Indah Sari et al, Pengembangan Model Pembelajaran Diskusi dan Personal Investigation dalam Meningkatkan Pemahaman Mahasiswa pada Mata Kuliah Evaluasi Pembelajaran di Universitas Batanghari

Pembelajaran Sejarah Kelas XI IPS di SMA

Negeri 1 Juwana Tahun Ajaran 2012/2013. FIS,

Universitas Negeri Semarang.

Subagiyo, A. 2010. (Tesis). Perbedaan Pembelajaran

Metode Ceramah dan Metode Demonstrasi

Terhadap Prestasi Belajar Mahasiswa S1

Keperawatan STIKES Muhammadiyah Lamongan. Universitas Sebelas Maret, Surakarta. (Tesis Dipublikasikan).

Suprijono, Agus. 2015. Cooperative Learning Teori dan Aplikasi PAIKEM (Revisi). Yogyakarta: Pustaka Belajar.

Sugiyono. 2014. Statistik Untuk Penelitian. Bandung: Alfabeta.

Trianto. 2014. Model-model Pembelajaran Inovatif Berorientasi Konstrukvistik. Jakarta: Prestasi Pustaka. 